\title{
Insights into a historic severe haze event in Shanghai: synoptic situation, boundary layer and pollutants
}

\author{
Chunpeng Leng ${ }^{1}$, Junyan Duan ${ }^{1}$, Chen Xu${ }^{1}$, Hefeng Zhang ${ }^{2}$, Yifan Wang ${ }^{1}$, Yanyu Wang ${ }^{1}, \mathrm{Xiang} \mathrm{Li}^{1}$, \\ Lingdong Kong ${ }^{1}$, Jun Tao ${ }^{3}$, Renjian Zhang ${ }^{4}$, Tiantao Cheng ${ }^{1,5}$, Shuping Zha ${ }^{5}$, and Xingna Yu ${ }^{5}$ \\ ${ }^{1}$ Shanghai Key Laboratory of Atmospheric Particle Pollution and Prevention (LAP ${ }^{3}$ ), Department of environmental science \\ and engineering, Fudan University, Shanghai 200433, China \\ ${ }^{2}$ Atmospheric Environment Institute, Chinese Research Academy of Environmental Sciences, Beijing 100012, China \\ ${ }^{3}$ South China Institute of Environmental Sciences, Ministry of Environmental Protection, Guangzhou 510655, China \\ ${ }^{4}$ Key Laboratory of Region Climate-Environment Research for Temperate East Asia, Institute of Atmospheric Physics, \\ Chinese Academy of Sciences, Beijing 100029, China \\ ${ }^{5}$ Key Laboratory of Meteorological Disaster of Ministry of Education, Nanjing University of Information Science and \\ Technology, Nanjing 210044, China
}

Correspondence to: Tiantao Cheng (ttcheng@fudan.edu.cn) and Xiang Li (lixiang@fudan.edu.cn)

Received: 25 August 2015 - Published in Atmos. Chem. Phys. Discuss.: 19 November 2015

Revised: 13 June 2016 - Accepted: 24 June 2016 - Published: 27 July 2016

\begin{abstract}
A historic haze event, characterized by lengthy, large-scale and severe pollution, occurred in the Yangtze River Delta (YRD) of China from 1 to 10 December 2013. This haze event significantly influenced air quality throughout the region, especially in urban areas. Aerosol physical, chemical and optical properties were measured in Shanghai. Sometimes the $1 \mathrm{~h}$ average particle concentration (e.g., $\mathrm{PM}_{2.5}$ ) exceeded $600 \mu \mathrm{g} \mathrm{m}^{-3}$. Inorganic water-soluble ions in particles, trace gases and aerosol optical coefficients had a similar tendency to increase evidently from clear to hazy episodes. A combination of various factors contributed to the formation and evolution of the haze event, among which meteorological conditions, local anthropogenic emissions and pollutants are the major factors. High pressure system, calm surface wind and subsidence airflow were responsible for the decrease of planetary boundary layer (PBL) and the accumulation of pollutants. Atmospheric visibility correlated strongly with relative humidity $(\mathrm{RH})$, particle number in size of 600-1400 $\mathrm{nm}$ other than particulate water-soluble species and particle mass $\left(\mathrm{PM}_{2.5}\right)$. The particle hygroscopicity plays an important role in atmospheric visibility reduction. The results are somewhat helpful to forecast and eliminate regional atmospheric pollution in China.
\end{abstract}

\section{Introduction}

Atmospheric aerosols are either emitted from human activities and natural sources or formed by a variety of precursor photochemical reactions. Aerosol exerts great impacts on the earth's radiation balance and climate by directly scattering and absorbing solar and terrestrial radiation, and indirectly modifying cloud and precipitation by acting as cloud condensation nuclei (CCN) (Ramanathan et al., 2001; Andreae et al., 2005; Lohmann and Feichter, 2005). In lower atmospheric layers, aerosol particles can accumulate and result in air pollution under unfavorable dispersion conditions, and then produce the adverse effects on human health and atmospheric visibility (Wu et al., 2005). Haze is an atmospheric phenomenon where the sky clarity is obscured by dust, smoke and other dry particles, during which atmospheric visibility and relative humidity $(\mathrm{RH})$ are usually below $10 \mathrm{~km}$ and $80 \%$ (Wu et al., 2006; Xiao et al., 2006; Fu et al., 2008; Bell et al., 2011).

Since World War II, haze has occurred in London and Los Angeles due to fast economic development (McNulty, 1968; Lee, 1983; Schichtel et al., 2001). After that, the regions affected by haze spread to Indian Ocean and Asia etc. (Quinn and Bates, 2003; Huebert er al., 2003; Du et al., 2011). Until now, the formation and evolution of haze has not been 
fully understood despite experiments having been carried out throughout the world, making it difficult for the governments to take effective measures to reduce air pollution (Malm and Day, 2001; Huebert et al., 2003; Wu et al., 2005; Wang et al., 2006b).

China has undergone rapid economic development for over 30 years, which releases a large amount of anthropogenic particles and relevant precursors, and forces many cities to suffer from atmospheric pollution. The increase of haze or hazy days has been observed in the urban environments of northern, eastern, and southwestern China (Sun et al., 2006; Che et al., 2009). Four major regions are mostly influenced by haze in China, i.e., the Jing-Jin-Tang Region (JJT), the Yangtze River Delta (YRD), the Sichuan Base (SCB) and the Pearl River Delta (PRD). The hazy days increased significantly from 70 days in 2001 to 144 days in 2004 in Guangzhou (Liu et al., 2013). Although the hazy days decreased quickly from 223 days in 1982 to 73 days in 2005 in Beijing after measures implemented on management of coal demand, motor vehicles, industrial and dust emissions, it increased again in 2011 and posed significant effects on society (Liu et al., 2013). Wang et al. (2006b) compared the aerosol chemical compositions of dusty, hazy and clear days in Beijing, and pointed out that $\left(\mathrm{NH}_{4}\right)_{2} \mathrm{SO}_{4}$, $\mathrm{NH}_{4} \mathrm{NO}_{3}$ and $\mathrm{Ca}\left(\mathrm{NO}_{3}\right)_{2}$ were the major species during hazy days in spring. Sun et al. (2006) found that the concentrations of aerosol elements and water-soluble ions in haze-fog episodes were over 10 times those in clear days in Beijing. The YRD region, one of the important economic core areas with a large population, high urbanization and advanced industrialization in China, is facing an inter-annual increase of foggy and hazy days, especially in winter (Tie and Cao, 2009). Ye et al. (2011) discovered the important role of ammonia in haze formation in Shanghai. Du et al. (2011) provided insights into summer haze events over Shanghai, and pointed out that the secondary pollutants of increasing sulfate and nitrate were oxidized from large amounts of $\mathrm{SO}_{2}$ and $\mathrm{NO}_{2}$ under a high atmospheric oxidation condition. Kang et al. (2013) regarded more accumulation mode particles and higher RH as the main reasons of atmospheric visibility impairment during haze episodes in Nanjing.

To date, available studies on haze in the YRD mainly put efforts to the chemical compositions and physical characteristics of pollutants, but in view of synoptic few focused on the entire process of events at larger scales. It is meaningful to investigate the formation and evolution of regional haze events for useful information to forecast and reduce severe atmospheric pollution. A winter haze event occurred in the YRD during 1-10 December 2013, known as one historic severe event with features of lengthy, large-scale and strong pollution. This paper performs a detailed analysis of this serious haze event and gives insights into regional heavy atmospheric pollution in such a fast-developing area.

\section{Experiment}

\subsection{Observation site}

The measurement station was mounted on the roof of one building approximately $20 \mathrm{~m}$ above ground on the campus of Fudan University $\left(31^{\circ} 18^{\prime} \mathrm{N}, 121^{\circ} 29^{\prime} \mathrm{E}\right)$ in Shanghai, located in the east edge of the YRD region. The site is mainly surrounded by urban residential and commercial zones, approximately $40 \mathrm{~km}$ from the East China Sea. Due to Asian monsoon climate, the annual mean precipitation is about $1119 \mathrm{~mm}$, mainly occurring between May and September, and the wind prevails northeasterly in winter and southeasterly in summer. Atmospheric components are likely to originate from local emissions and remote sources (Du et al., 2011). Local time (LT) used in this study is 8 hours ahead of UTC.

\subsection{Instrument and measurements}

Major water-soluble ions $\left(\mathrm{Na}+, \mathrm{K}^{+}, \mathrm{Mg}^{+}, \mathrm{Ca}^{+}, \mathrm{SO}_{4}^{2-}, \mathrm{Cl}^{-}\right.$, $\mathrm{NO}_{3}^{-}$and $\mathrm{NH}_{4}^{+}$) in aerosol particles were measured by an analyzer for Monitoring Aerosols and Gases (MARGA, ADI 2080, Netherlands) at $1 \mathrm{~h}$ time resolution. Ambient air is drawn into the sample box with airflow of $1 \mathrm{~m}^{3} \mathrm{~h}^{-1}$ by a pump with mass flow controller (MFC), and the separated gases and aerosols are selectively dissolved and then analyzed by ion chromatography. An internal calibration method, using bromide for the anion chromatograph and lithium for the cation chromatograph, was operated over the whole period to ensure the instrument would identify and measure ion species successfully. The detailed information of sampling, operation and internal calibration can be found elsewhere (Du et al., 2011).

Aerosol particle size distributions in $10 \mathrm{~nm}-10 \mu \mathrm{m}$ were observed using a high-resolution wide-range particle spectrometer (WPS-1000 XP, MSP). The description of instrument, combining laser light scattering (LPS), condensation particle counting (CPC) and differential mobility analysis (DMA), has been introduced in detail by Gao et al. (2009). DMA and CPC can effectively count particles in $10-500 \mathrm{~nm}$, while LPS is designed to measure particles in $350 \mathrm{~nm}-10 \mu \mathrm{m}$. The instrument took 3 min to scan the entire size range completely, 60 channels in DMA and 24 channels in LPS (2 s per channel). Before the campaign, DMA was calibrated using the National Institute of Standards and Technology (NIST) standard reference materials (SRM) 1691 and SRM 1963 polystyrene latex (PSL) spheres (mean diameter of 0.269 and $0.1007 \mu \mathrm{m}$ ) to maintain proper transfer function and accurate particle sizing. LPS was calibrated using four NIST traceable sizes of PSL (i.e., 0.701, 1.36, 1.6 and $4.0 \mu \mathrm{m}$ ). Zhang et al. (2010) described the calibration and operation methodology of WPS in detail.

Black carbon (BC) was measured by an Aethalometer (AE-31, Magee Scientific Co., USA) at 5 min time resolution 
and $5 \mathrm{~L} \mathrm{~min}^{-1}$ airflow rate. According to the strong ability of $\mathrm{BC}$ absorption to near-infrared lights, its mass can be determined using the light attenuation at $880 \mathrm{~nm}$ and the appropriate specific attenuation cross section proportional to $\mathrm{BC}$ (Petzold et al., 1997). The attenuation is calculated based on the intensity difference of reference and sensing beams between light on and off (Hansen et al., 1984; Weingartner et al., 2003). In order to screen the impacts of other absorptive material, the data contaminated by mineral aerosols were excluded from BC measurements. Details for instrument operating and calibrating and data processing can be found in Cheng et al. (2010).

Aerosol backscattering profile was measured by a set of micro-pulse lidar (MPL-4B) with pulse energy of 6-10 $\mu \mathrm{J}$ and repetition frequency of $2500 \mathrm{~Hz}$. To date, MPL is utilized widely in most parts of world as an effective tool for capturing high temporal resolution information of aerosol vertical distributions (Menut et al., 1999; Cohn and Angevine, 2000; Brooks, 2003). Planetary boundary layer (PBL) height is determined by the MPL measurement at the altitude where a sudden decrease of scattering coefficients occurs (Boers and Eloranta, 1986). Instrument calibrations, normalization process, and the analyses of errors propagation and correction uncertainties in MPL processed signal have been described by Campbell et al. (2002), Welton and Campbell (2000) and Welton et al. (2002).

Aerosol scattering coefficients $(525 \mathrm{~nm})$ were measured using an Aurora-1000 nephelometer (Ecotech Pty Ltd., Australia) at 5 min resolution. The scattering coefficient is calculated by integrating the scattering intensities from angles 7 to $170^{\circ}$. The relative humidity $(\mathrm{RH})$ inside the instrument was retained below $60 \%$ to prevent excessive water vapor from entering the chamber. The zero check was operated automatically each day using particle-free air, while the span check was done every 2 weeks using R-134a gas.

A CCN counter (CCN-100, DMT, USA) with continuous flow and single column (Roberts and Nenes, 2006; Lance et al., 2006) was employed to monitor CCN concentrations at supersaturations (SS) of $0.2-1.0 \%$. The ambient aerosols were firstly dried by a dryer (activated carbon) to lower relative humidity (RH) below $30 \%$, and subsequently introduced into the counter. The instrument has been calibrated for SS using standard $\left(\mathrm{NH}_{4}\right)_{2} \mathrm{SO}_{4}$ particles every 3 months since 2010. According to the instrument operation manual, regular calibrations were also performed for temperature gradient, input and shear airflows and pressure to maintain stable SS (Leng et al., 2013, 2014a, b). Periodic zero checks were done to ensure counting accuracy for optical particle counter (OPC) inside the $\mathrm{CCN}$ counter.

Moreover, two continuous ambient particulate monitors (FH62C14, Thermo) were used to measure $\mathrm{PM}_{2.5}$ and $\mathrm{PM}_{10}$ (particles in aerodynamic diameter $<2.5$ and $<10 \mu \mathrm{m}$ ). The particles are deposited on a glass fiber tape, and then detected by the method of beta attenuation. The particle mass concentration is obtained from the simultaneous measurements of mass and volume of one aerosol sample. An automatic weather station (HydroMet, Vaisala) and a visibility monitor (Vaisala) were employed to measure meteorological variables and atmospheric visibility. The data of hourly averaged concentration of gases $\left(\mathrm{SO}_{2}, \mathrm{NO}_{2}, \mathrm{CO}\right.$ and $\left.\mathrm{O}_{3}\right)$ were from the Shanghai Environmental Monitoring Center (SEMC).

\section{Results and discussion}

\subsection{Overview of haze event}

\subsubsection{Identification of hazy episode}

The key criterion for discerning a haze event is an apparent decrease of atmospheric visibility less than $10 \mathrm{~km}$ and ambient relative humidity (RH) below $80 \%$ lasting for several hours (Fu et al., 2008; Du et al., 2011). When $80 \%<\mathrm{RH}<90 \%$, the event is referred to as a complex of haze-fog co-occurring or transition (Leng et al., 2014a), and it is also classified as hazy episode in the present study.

Figure 1a depicts the temporal variations of hourly $\mathrm{PM}_{2.5}, \mathrm{PM}_{10}$, atmospheric visibility and meteorological factors from 1 to 10 December 2013. On the whole, atmospheric visibility mostly declined to below $10 \mathrm{~km}$, and $\mathrm{RH}$ hardly reached $90 \%$. The haze event constituted several subepisodes, marked by gray areas in Fig. 1a. It was clear that Shanghai suffered from a long-term haze event until 10 December, and subsequently loosened when atmospheric visibility improved and the clean sky took control afterwards. In fact, these hazy sub-episodes approximately accounted for $70 \%$ of the entire period, with mean atmospheric visibilities of $5.65 \mathrm{~km}$ for the former compared to $29.45 \mathrm{~km}$ for the rest $(30 \%)$.

On a larger scale, this haze event caused a historic atmospheric pollution, and attacked most parts of central and eastern China. $\mathrm{PM}_{2.5}$ in many cities exceeded $150 \mu \mathrm{g} \mathrm{m}^{-3}$, and some more than $300-500$ even $600 \mu \mathrm{g} \mathrm{m}^{-3}$; as expected, this event will cause invisible but serious problems to people's health in the following days (Cao et al., 2012).

\subsubsection{Meteorological conditions}

Precipitation did not appear during the whole campaign. For most of the period (Fig. $1 \mathrm{~b}$ and $\mathrm{c}$ ), ambient RH and temperature correlated negatively and showed an evident diurnal pattern, varying in the ranges of $20-87 \%$ and $6-17^{\circ} \mathrm{C}$, respectively. The hazy episodes were usually characterized by higher RH and lower temperature, while the clean periods often corresponded to lower RH and higher temperature. The main reason is that high temperature can strengthen the vertical dispersion of pollutants due to thermal effects, and high RH can facilitate aerosol scattering due to hygroscopicity. The wind was weak $\left(<2 \mathrm{~m} \mathrm{~s}^{-1}, 87 \%\right)$ during the hazy episodes until 9 December, but the following day it became strong $\left(>4 \mathrm{~m} \mathrm{~s}^{-1}\right)$ and conductive to the dispersion of air 


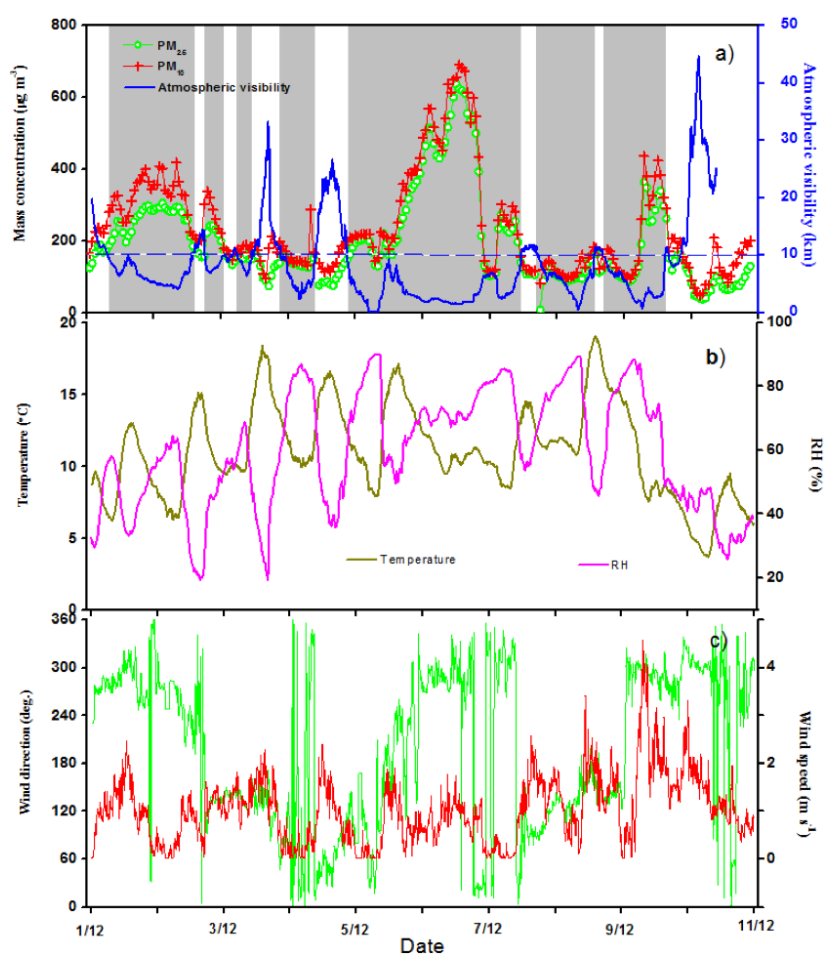

Figure 1. (a) Temporal variations of $\mathrm{PM}_{2.5}, \mathrm{PM}_{10}$ and atmospheric visibility (vis) measured in Shanghai from 1 to 10 December 2013. The dashed line is visible at $10 \mathrm{~km}$. (b, c) show temporal variations of meteorological parameters from 1 to 10 December 2013.

pollutants due to a transiting cold front (Fig. $1 \mathrm{~b}$ and c). The wind direction was basically northeast or southeast during the clean periods, originating from marine areas. However, the wind normally turned into northwest when the haze took over, which will probably bring a large quantity of pollutants from inland areas and to some extent cause pollutant accumulation in downwind.

\subsubsection{Particulate mass concentration}

$\mathrm{PM}_{2.5}$ and $\mathrm{PM}_{10}$ were employed to represent ambient particulate mass burden per volume in the atmospheric boundary layer. One hour average $\mathrm{PM}_{2.5}$ and $\mathrm{PM}_{10}$ ranged within 50-600 and 55-680 $\mu \mathrm{g} \mathrm{m}^{-3}$ throughout the whole campaign (Fig. 1a), and both of them significantly rose during the hazy episodes with averages of 315 and $333 \mu \mathrm{g} \mathrm{m}^{-3}$, compared to 112 and $134 \mu^{-3} \mathrm{~m}^{-3}$ in the clean periods. On the other hand, the ratios of $\mathrm{PM}_{2.5} / \mathrm{PM}_{10}$ varied between 0.54 and 0.97 , and averaged at $0.88,0.93,0.8$ in total, hazy and clean periods, indicating that the fine particles are major contributors to particle mass.

Interestingly, both $\mathrm{PM}_{2.5}$ and $\mathrm{PM}_{10}$ reached their peaks of 600 and $680 \mathrm{\mu g} \mathrm{m}^{-3}$ as new historic records on 6 December, approximately 14 times higher than the Grade I criteria of the National Ambient Air Quality Standard of China $\left(50 \mu \mathrm{g} \mathrm{m}^{-3}\right.$ for $\left.\mathrm{PM}_{10}\right)$, and 24 times the World Health Or-

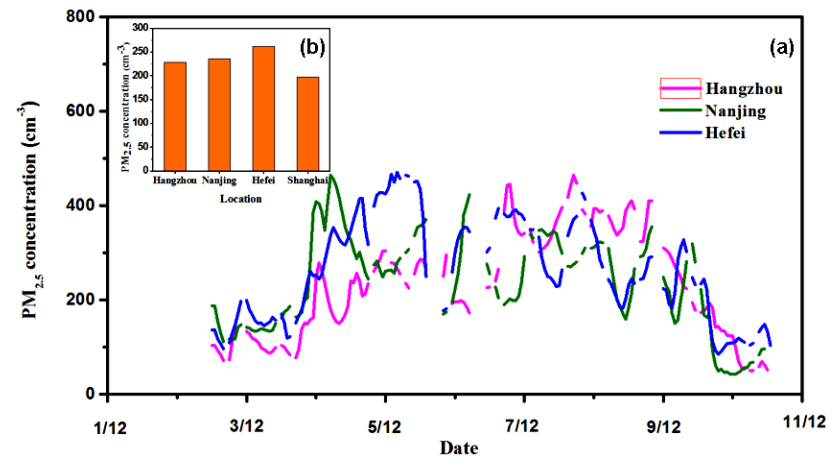

Figure 2. Temporal variations of $\mathrm{PM}_{2.5}$ in Hangzhou, Nanjing and Hefei (a) and their mean concentrations from 1 to 10 December 2013 .

ganization Air Quality Guidelines $\left(25 \mu \mathrm{g} \mathrm{m}^{-3}\right.$ for $\left.\mathrm{PM}_{2.5}\right)$. Other cities in the YRD showed a similar tendency and high $\mathrm{PM}_{2.5}$ along with this haze event; such as $226 \mu \mathrm{g} \mathrm{m}^{-3}$ in Hangzhou, $230 \mu \mathrm{g} \mathrm{m}^{-3}$ in Nanjing and $260 \mu \mathrm{g} \mathrm{m}^{-3}$ in Hefei (Fig. 2). The numerous measurements earlier in Shanghai during the last decade showed much lower values. For example, Wang et al. (2006a) observed that $\mathrm{PM}_{2.5}$ varied within $17.8-217.9 \mu \mathrm{g} \mathrm{m}^{-3}$ and averaged at $94.6 \mu \mathrm{g} \mathrm{m}^{-3}$. According to the Shanghai Environmental Bulletin 2010 (SEB, 2010, www.envir.gov.cn/law/bulletin/2010/), the annual average of $\mathrm{PM}_{10}$ in 2009 was about $79 \mu \mathrm{g} \mathrm{m}{ }^{-3}$. Leng et al. (2014a) reported $\mathrm{PM}_{2.5}$ average of $143 \mu \mathrm{g} \mathrm{m}^{-3}$ during hazy episode and $46 \mu \mathrm{g} \mathrm{m}^{-3}$ during clear episode in November 2010. They also observed that $\mathrm{PM}_{2.5}$ varied in $10-210 \mu \mathrm{g} \mathrm{m}^{-3}$ in January 2011 and $10-130 \mu \mathrm{g} \mathrm{m}^{-3}$ in April 2012, respectively (Leng et al., 2013, 2014b). In addition, compared to Beijing as another megacity in China, He et al. (2001), Sun et al. (2004) and Liu et al. (2013) monitored $\mathrm{PM}_{2.5}$ extremes of $357 \mu \mathrm{g} \mathrm{m}^{-3}$ from July 1999 to September $2000,349 \mu \mathrm{g} \mathrm{m}^{-3}$ in winter from 2002 to 2003, and $220 \mu \mathrm{g} \mathrm{m}^{-3}$ in September 2011. Briefly, the particulate mass burden was extremely high in this haze event, and so serious air pollution, unsuitable for human beings (Liu et al., 2013), must cause a formidable environmental disaster.

\subsubsection{High aerosol columnar loading}

Aerosol optical depth (AOD), retrieved from MODIS employing the algorithm well introduced by Li et al. (2005), can be taken as a good indicator of aerosol loading in the whole atmosphere. Figure 3 depicts a full feature of AOD spatial distribution and its day-to-day development during the haze event. Briefly, the covering region of high AODs $(>0.5)$ was generally spreading out a big domain about most of southern China. High AODs originated from the YRD and the SCB, then extended to central southern China, southwestern China and even south of the JJT region, and moved to the YRD area in the end. 

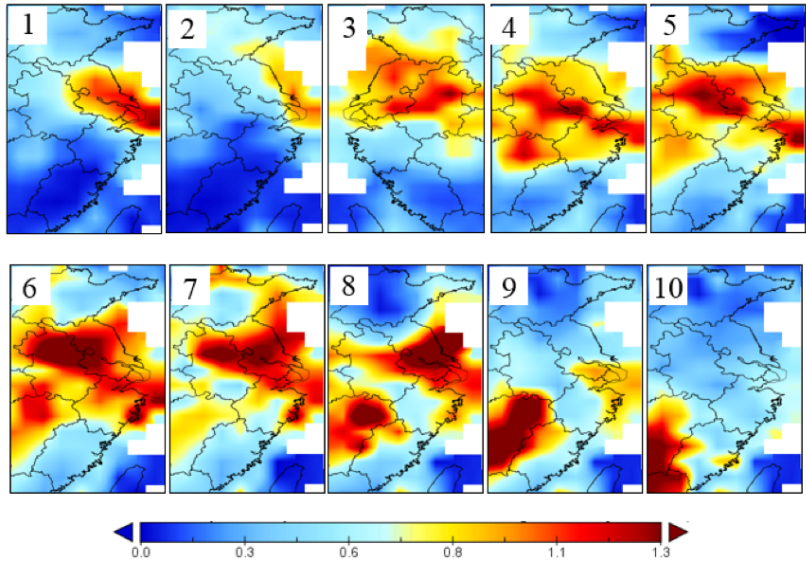

Figure 3. Aerosol optical depth (AOD) at $550 \mathrm{~nm}$ from MODIS over the YRD region at 06:00 (UTC) from 1 to 10 December 2013 (http://modis.gsfc.nasa.gov/).

During the most serious days, AODs were as high as $1.00-1.25$ on $5-8$ December. According to the records of the Ministry of Environmental Protection of China (http: //www.zhb.gov.cn/), many cities in the upwind areas (e.g., Nanjing, Wuxi, and Suzhou) had higher AODs up to 1.5 and an air quality index (AQI) over 500, implying that the inflow of pollutants to Shanghai will inevitably contribute to the pollution. In addition, the weak circulation (Sect. 3.2.1) normally led to the build-up of pollutant pooling and contributed to the haze event formation.

\subsubsection{Aerosol optical properties}

Figure 4 shows a temporal series of $\mathrm{BC}$, aerosol scattering coefficient $\mathrm{Sc}(525 \mathrm{~nm})$, and aerosol absorption coefficient $\mathrm{Ab}(532 \mathrm{~nm})$. Based on the assumption that the averaged mixing state of $\mathrm{BC}$ is uniform, the $\mathrm{Ab}$ coefficient is indirectly calculated from measured $\mathrm{BC}$ according to the following equation (Yan et al., 2008),

$\mathrm{Ab}=\alpha \times[\mathrm{BC}]$

where $[\mathrm{BC}]$ represents $\mathrm{BC}$ mass concentration, and $\alpha$ is $\mathrm{BC}$ absorption efficiency which is adopted as $8.28 \mathrm{~g} \mathrm{~m}^{-2}$ in this paper. This value was obtained from the inter-comparison experiment performed in southern China previously, and was within the variance range of various source regions (Bergin et al., 2001; Bond and Bergstrom, 2006; Yan et al., 2009; Zhao et al., 2013). The aerosol scattering and absorption coefficients in combination determine its extinction ability, namely aerosol extinction coefficient $(\mathrm{Ex}=\mathrm{Ab}+\mathrm{Sc})$.

Basically, BC, Sc and Ab had the same tendency to increase in the hazy episodes, and reached their max values

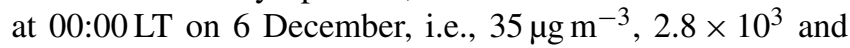
$290 \mathrm{M} \mathrm{m}^{-1}$, approximately $4-5$ times higher than their mean values in the clean periods $\left(8.3 \mu \mathrm{g} \mathrm{m}^{-3}, 643\right.$ and $\left.58 \mathrm{M} \mathrm{m}^{-1}\right)$.

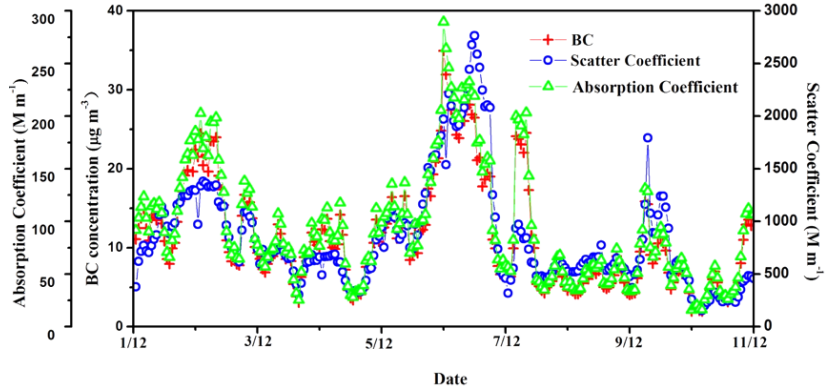

Figure 4. Temporal variations of black carbon (BC) concentration, aerosol scattering $(\mathrm{Sc})$ and absorptive $(\mathrm{Ab})$ coefficients from 1 to 10 December 2013.

The enhancement of aerosol optical properties largely contributed to atmospheric visibility decreasing, which correspondingly deteriorated to its minimum of $50 \mathrm{~m}$ at the same moment (Fig. 1). The mean aerosol single scattering albedo $(\mathrm{SSA}=\mathrm{Sc} / \mathrm{Ex}, 532 \mathrm{~nm})$ was expectedly low at 0.89 , indicating more absorptive species existing in the particle group.

\subsubsection{Condensation nuclei and cloud condensation nuclei}

Aerosol size distribution was analyzed in detail to shed some light on its relationship with haze. Figure 5a presents a time series of aerosol size spectra and integrating particle sizeresolved number concentrations $\left(N_{\mathrm{CN}}\right) . N_{\mathrm{CN}}$ showed an evident diurnal pattern with two peaks corresponding to the traffic rush hours, and a higher mean and instantaneous values appeared in the hazy episodes $\left(15000\right.$ and $25000 \mathrm{~cm}^{-3}$ ) than the clean periods (9500 and $\left.17000 \mathrm{~cm}^{-3}\right)$. Generally, ambient aerosol particles in higher loading were mainly distributed in a wider size range over the hazy episodes than the clean periods: $20-200 \mathrm{~nm}$ for the former and $20-100 \mathrm{~nm}$ for the latter. The averaged aerosol number size distribution is shown in Fig. 5b. About $67 \%$ of particles fell in the size range of $10-100 \mathrm{~nm}$, and the percent further increased to $91 \%$ when enlarged to $10-200 \mathrm{~nm}$. This result is in good agreement with the early observations that urban ambient aerosols mainly distribute in ultrafine size section (Woo et al., 2001; Gao et al., 2007), slightly higher than $62 \%$ reported in Nanjing and $61 \%$ in Atlanta, a little lower than $72 \%$ in Eastern Germany and significantly lower than $94 \%$ in Taicang (Woo et al., 2001; Tuch et al., 1997; Gao et al., 2009; Kang et al., 2013).

Cloud condensation nuclei $(\mathrm{CCN})$ constitute an important fraction of atmospheric aerosol population, and can indirectly influence global climate change through modifying the microphysical and radiative properties and lifetime of cloud (IPCC, 2013). It tends to reduce cloud droplet size and then suppress the wet precipitation in shallow and shortlived clouds (Lohmann and Feichter, 2005). Previous studies in Shanghai have found that CCN number concentration 


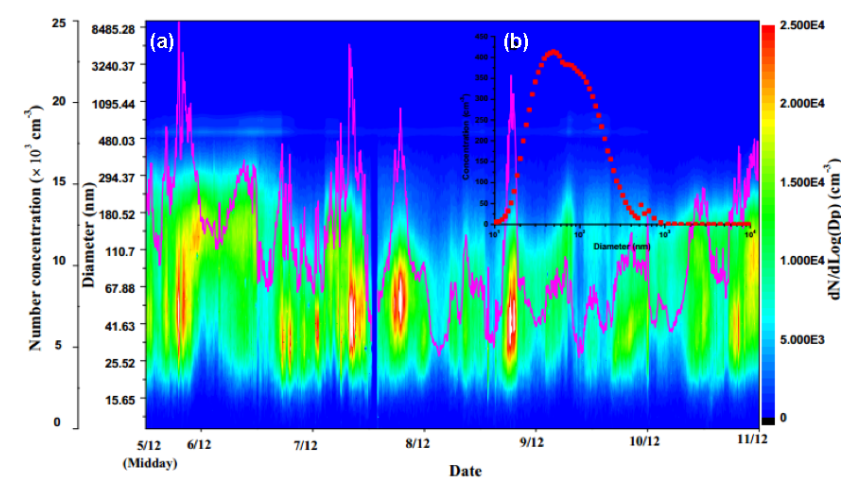

Figure 5. (a) Time series of 4-min mean aerosol number size spectra and aerosol number concentration (pink line) and (b) averaged aerosol number size distribution from 5 to 10 December 2013.

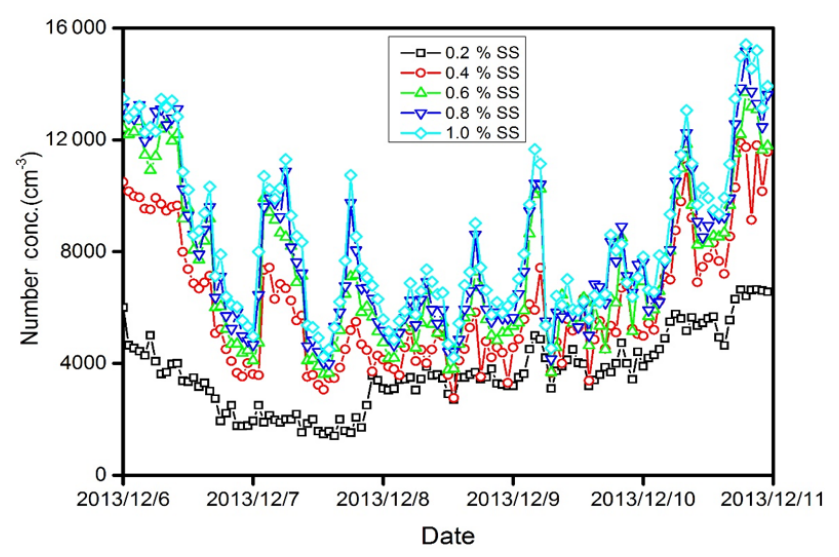

Figure 6. Time series of $1 \mathrm{~h}$ mean $\mathrm{CCN}$ concentration $\left(N_{\mathrm{CCN}}\right)$ at supersaturations (SS) of $0.2-1.0 \%$ from 6 to 10 December 2013 .

$\left(N_{\mathrm{CCN}}\right)$ and aerosol activity promotes effectively during the polluted periods (Leng et al., 2013, 2014a). In north India, Ritesh et al. (2007) observed a significant impact of winter haze on $N_{\mathrm{CCN}}$. To gather more information about $\mathrm{CCN}$ during haze, hourly $N_{\mathrm{CCN}}$ at SS of $0.2-1.0 \%$ were plotted as a function of time in Fig. 6. As expected, $N_{\mathrm{CCN}}$ increased with SS, i.e., $3800-10000 \mathrm{~cm}^{-3}$ at SS $0.2 \%$ and $4000-16000 \mathrm{~cm}^{-3}$ at SS $1.0 \%$, and exhibited bimodal daily distributions. $N_{\mathrm{CCN}}$ related well with $N_{\mathrm{CN}}$, and $N_{\mathrm{CCN}}$ greatly enhanced during the hazy episodes, about $1.6-1.8$ fold (on varying SS) of that during the clean periods.

\subsubsection{Aerosol chemical species}

A key for understanding haze is to characterize both aerosol composition and trace gases quantitatively (Du et al., 2011). As important components of atmospheric particles, watersoluble inorganic ions are thought to be a significant contributor to atmospheric visibility impairment (Kang et al., 2013).

The time series of hourly water-soluble inorganic ions in $\mathrm{PM}_{2.5}$, including $\mathrm{Na}^{+}, \mathrm{K}^{+}, \mathrm{Mg}^{+}, \mathrm{Ca}^{+}, \mathrm{SO}_{4}^{2-}, \mathrm{Cl}^{-}, \mathrm{NO}_{3}^{-}$

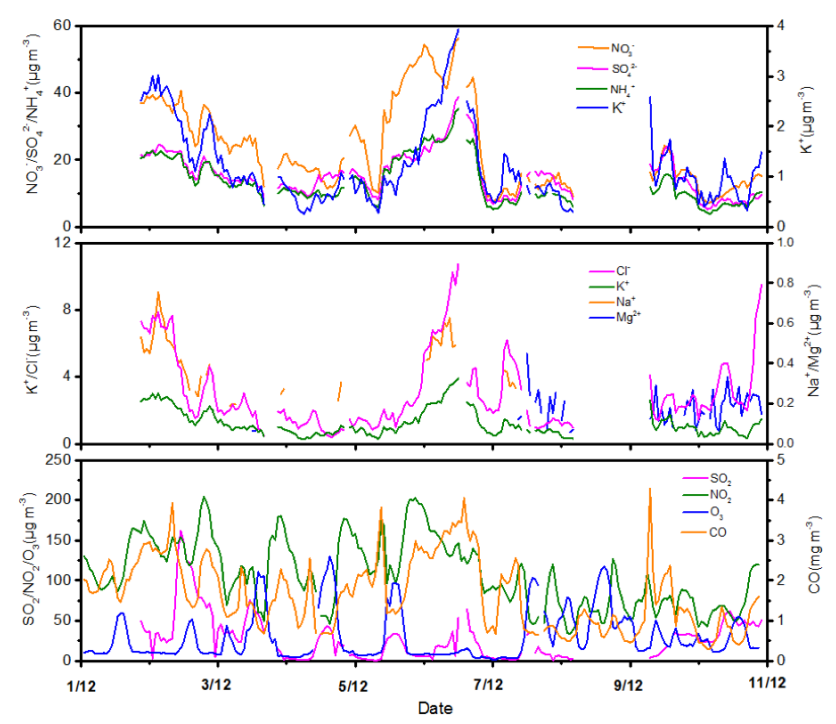

Figure 7. Temporal variations of chemical species in particles from 1 to 10 December 2013.

and $\mathrm{NH}_{4}^{+}$, and gaseous pollutants such as $\mathrm{SO}_{2}, \mathrm{NO}_{2}, \mathrm{CO}$ and $\mathrm{O}_{3}$ from 1 to 10 December are presented in Fig. 7. Aerosol water-soluble ions, highly coinciding with particulate mass, showed higher contents in the hazy episodes than the clean periods. Totally, the mean concentrations of these ions were comparable to that monitored earlier in Shanghai (Yao et al., 2002; Wang et al., 2006a; Du et al., 2011). The mean concentrations of these ions were in sequence of $\mathrm{NO}_{3}^{-}>\mathrm{SO}_{4}^{2-}>\mathrm{NH}_{4}^{+}>\mathrm{Cl}^{-}>\mathrm{K}^{+}>\mathrm{Na}^{+}>\mathrm{Mg}^{2+}$, and their contributions to $\mathrm{PM}_{2.5}$ were 11.7, 7.7, 6.7, 1.5, 0.6, 0.3 and $0.08 \%$, respectively, slightly higher than that observed in haze pollution in Nanjing and Guangzhou (Tan et al., 2009; Kang et al., 2013). Overall, the integrated water-soluble ions accounted for $28.5 \%$ of $\mathrm{PM}_{2.5}$, higher than the dust event but significantly lower than the biomass burning event observed in Nanjing (Zhang et al., 2012).

Gaseous species play a vital role in atmospheric process by acting as precursors or mediums of photochemical reactions. Among them, $\mathrm{O}_{3}$ has been widely known as the products of photochemical reactions between volatile organic compounds (VOCs) and nitrogen oxides $\left(\mathrm{NO}_{x}\right)$ with the participation of heat and sunlight, while $\mathrm{SO}_{2}, \mathrm{NO}_{2}$, and $\mathrm{CO}$ are mainly emitted from biomass, fuel and coal burning (Seinfeld and Pandis, 2006). Shown in Fig. 7, the measured gaseous pollutants exhibited an increasing trend during the hazy episodes, with one exception of $\mathrm{O}_{3}$ probably due to consumption by oxidation of NO and other species (Liu et al., 2013).

$\mathrm{NO}_{3}^{-}$and $\mathrm{SO}_{4}^{2-}$ are products of $\mathrm{NO}_{2}$ and $\mathrm{SO}_{2}$ due to atmospheric oxidation; hence their concentrations strongly depended on related gaseous precursors and oxidation rate in the atmosphere. Two equations are used to estimate the extent of this transformation process (Sun et al., 2006): 

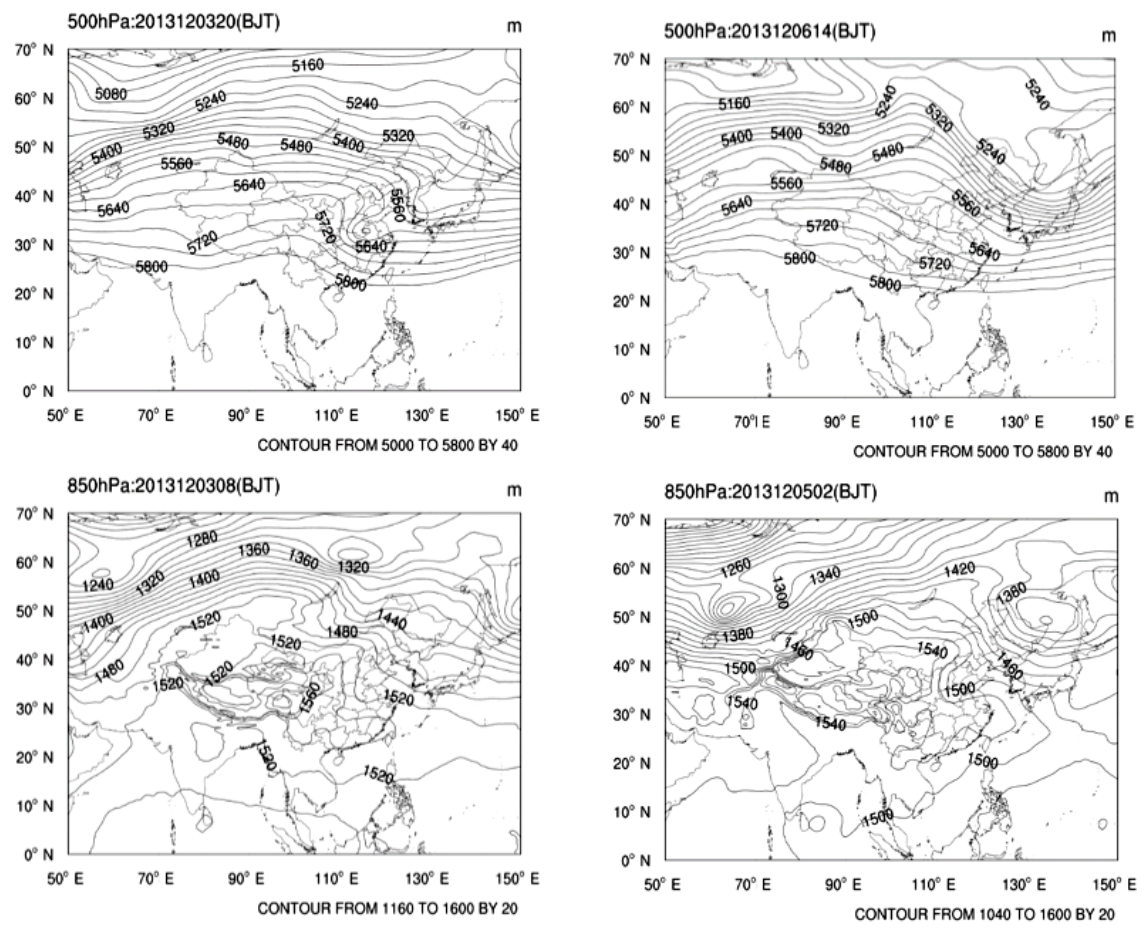

Figure 8. Atmospheric circulation situation at 500 and 850 hPa from 3 to 6 December 2013.

$\mathrm{NOR}=n \mathrm{NO}_{3}^{-} /\left(n \mathrm{NO}_{3}^{-}+n \mathrm{NO}_{2}\right)$

$\mathrm{SOR}=n \mathrm{SO}_{4}^{2-} /\left(n \mathrm{SO}_{4}^{2-}+n \mathrm{SO}_{2}\right)$,

where NOR and SOR means nitrogen oxidation rate and sulfur oxidation rate, $n$ refers to molar concentration. It can be easily deduced that larger NOR and SOR would generate more atmospheric aerosols, and atmospheric photolysis reaction of $\mathrm{SO}_{2}$ would take place if the oxidation rate exceeds 0.1 (Ohta and Okita, 1990). In this study, NOR and SOR were always higher than 0.1 with averages of 0.14 and 0.27 , respectively, suggesting that atmospheric oxidation of $\mathrm{NO}_{2}$ and $\mathrm{SO}_{2}$ contributed significantly to the formation of particulate matter. The mean NOR was comparable to that in Nanjing (0.16) during a long-lasting haze event but apparently lower than in Guangzhou (0.24), while the SOR was much higher than in Nanjing (0.13) but comparable to the value in Guangzhou (0.26) (Tan et al., 2009; Kang et al., 2013). Meanwhile, $\mathrm{NO}_{2}$ overwhelmingly surpassed $\mathrm{SO}_{2}$ with a mass ratio of 1.53 , hence more atmospheric $\mathrm{H}_{2} \mathrm{O}_{2}$ and $\mathrm{OH}$ would be removed via reactions with $\mathrm{NO}_{2}$, and the formation of $\mathrm{SO}_{4}^{2-}$ would be greatly suppressed due to the competition effect (Poppe et al., 1993). Furthermore, the mass ratio of ambient nitrate to sulfate $\left(\mathrm{NO}_{3}^{-} / \mathrm{SO}_{4}^{2-}\right)$ can help to track the relative importance of stationary vs. mobile sources of nitrate and sulfur in the atmosphere (Yao et al., 2002). The stationary emission dominates in the sources of $\mathrm{SO}_{2}$ and $\mathrm{NO}_{2}$ if the ratio is less than 1.0; otherwise $\mathrm{SO}_{2}$ and $\mathrm{NO}_{2}$ mainly come from traffic activities (Huebert et al., 1988). Shanghai has been experiencing an increasing trend of $\mathrm{NO}_{3}^{-} / \mathrm{SO}_{4}^{2-}$ because of the very fast development of motor vehicles over the past decade (Yao et al., 2002; Wang et al., 2006a; Fu et al., 2008). Therefore, more contribution of pollutants from mobile sources is expected to the local pollution. The mean $\mathrm{NO}_{3}^{-} / \mathrm{SO}_{4}^{2-}$ during this haze event was 1.53 , comparable to our early measurement in 2010 (1.61), but significantly higher than those observed in haze events in Guangzhou (1.02) and Nanjing (0.84 and 1.05) (Tan et al., 2009; Kang et al., 2013; Leng et al., 2013). The traffic-emitted $\mathrm{SO}_{2}$ and $\mathrm{NO}_{2}$ preponderating their stationary sources so conspicuous illustrated that the increasing traffic activities are one of main reasons for visibility degradation.

\subsection{Formation and evolution of haze event}

\subsubsection{Atmospheric circle and synoptic situation}

During wintertime, the YRD region is often influenced by cold air from the north, such as cold high pressure and cold front, and surface temperature inversion takes place sometimes (Chen et al., 2003; Liu et al., 2013). Under those conditions, atmospheric mixing and dispersion are basically weak in favor of pollutant accumulation, hence haze or fog easily occurs (Xu et al., 2011; Zhao et al., 2013).

The mean geopotential height field at $500 \mathrm{hPa}$ revealed that during 1-10 December a long wave adjustment happened over the middle and high latitude of Eurasia. On 1 to 5 De- 


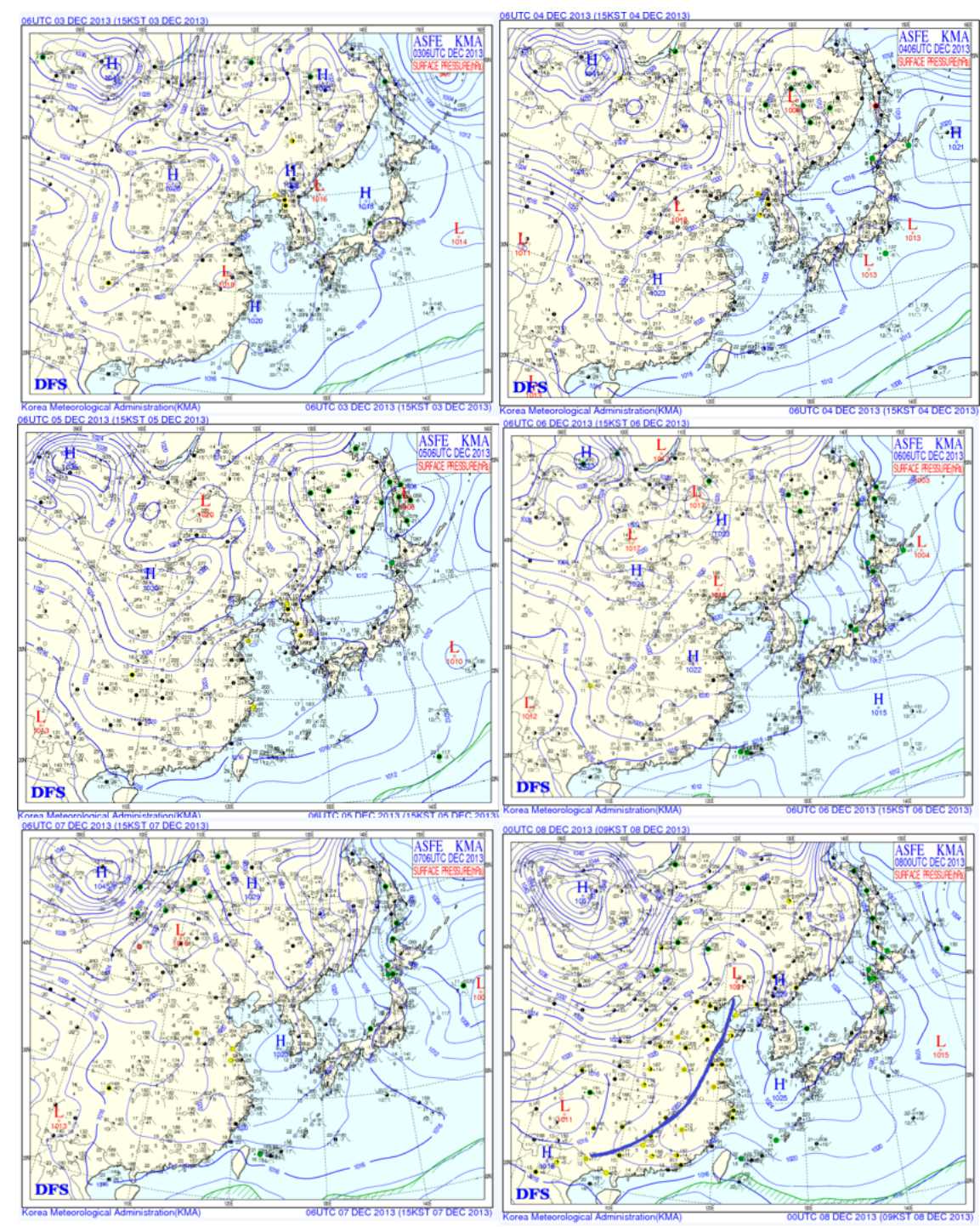

Figure 9. Surface weather maps from 3 to 8 December 2013. The black circles denote the measurement site (http://qixiangxinxifabupingtai. ejinqiao.com).

cember, the atmospheric circulation in this region was representative of two troughs and one ridge, and these troughs were located in the west of the Balkhash lake and the north of northeastern China and a wide ridge of high pressure existed between them (Fig. 8). On 6 December, the circulation situation changed to two troughs and two ridges, and these troughs were located in the west of Lake Baikal and the east of Asia. However, over the central and southern China, there were flat westerly flows most of the time with smaller radial degree and fast-moving short-wave troughs and ridges. During the haze event, central and southern China was mainly under the stable westerly, and the YRD was affected by it. Additionally, at $700 \mathrm{hPa}$, the shear lines generated continuously and moved eastwards, and the difference between temperature and dew point mostly exceeded $4^{\circ}$, and the weak westerly and wind convergence appeared over the areas covered by haze clouds. At $850 \mathrm{hPa}$, the YRD was influenced by an anticyclonic ring most of the time; the wind speed was smaller, even static; and in view of temperature, this region was in one weak warm structure and the isotherms were relatively flat.

The surface weather maps at 06:00 (UTC) from 3 to 8 December are shown in Fig. 9. A slowly migrating anti-cyclone (high-pressure) overlaid the YRD region and possibly caused a build-up of pollution due to the concomitant subsidence airflow and relatively stagnant conditions. The high pressure dominating this area also indicated aloft airflow convergence and surface divergence, which in turn would subside and restrict PBL development, and accordingly limit the convection of pollutants by trapping them within a shallow 
altitude. Unfavorable ambient temperature posed another adverse effect on the thermal dynamic development of PBL height. The small pressure gradients over the YRD would horizontally suppress the air circulation at large scales because of low wind speed mostly below $2 \mathrm{~m} \mathrm{~s}^{-1}$ during the hazy episodes. Under those favorable situations, e.g., stable synoptic condition and calm wind, atmospheric pollutants were easy to accumulate within the surface atmospheric layer which ultimately led to severe urban air pollution. On the other hand, the YRD was sometimes controlled by low pressure periphery and trough, and the pressure gradient was relatively weak. Although the low pressure was conducive to the rise of air masses, the vertical movement of upper and lower levels of the atmosphere was too weak to produce the effective dispersion of air pollutants and then result in pollution. Furthermore, the effect of ambient aerosols uptaking water vapor would effectively enhance their ability of scattering or absorbing solar radiation and damage atmospheric visibility eventually. The high ambient RH (60-80\%) over this haze process indeed made a rich supply of water vapor for enhancing aerosol hygroscopic growth and was mostly responsible for the atmospheric visibility impairment. Normally, external forces such as high wind or rainfall are necessary to interrupt the stable situation and favor the diffusion of pollutants.

Over the target region $\left(30^{\circ} 40^{\prime} \sim 31^{\circ} 53^{\prime}\right)$, during the haze event, the vertical winds were almost less than $0.4 \mathrm{~Pa} \mathrm{~s}^{-1}$ between $500 \mathrm{hPa}$ and surface, and it was less than $0.2 \mathrm{~Pa} \mathrm{~s}^{-1}$ at $700 \mathrm{hPa}$, implying that the vertical exchange of air parcels between the upper and lower atmospheric layers is very weak. Near the ground, the vertical velocity of winds was positive, and the relative vorticity was zero or negative value most of the time, demonstrating that airflow was prevailed in downdraft at the bottom of the atmosphere. Moreover, the temperature profile of sounding data revealed that the strong inversions occurred in 5 days with relatively low heights, so atmospheric convection and turbulence were inhibited, and then the blocked diffusion in vertical direction caused pollutant accumulation near the surface.

In summary, atmospheric pollutants were restricted within shallow layer, favorable for visibility impairment due to the dominance of a weak high-pressure system with lowpressure gradients, subsidence airflow, unfavorable PBL height and meteorological situation. In good agreement with our study, Wu et al. (2005) reported that descending air motion and weak horizontal wind produced significantly high particle concentrations during a severe haze event in Guangzhou. Also in the YRD area, Fu et al. (2008) found that a high-pressure system responsible for stagnant conditions was the major reason of high-pollution events. The stable synoptic condition and its long duration was indeed viewed as one of the most important factors ruling the formation and evolution of this haze event.

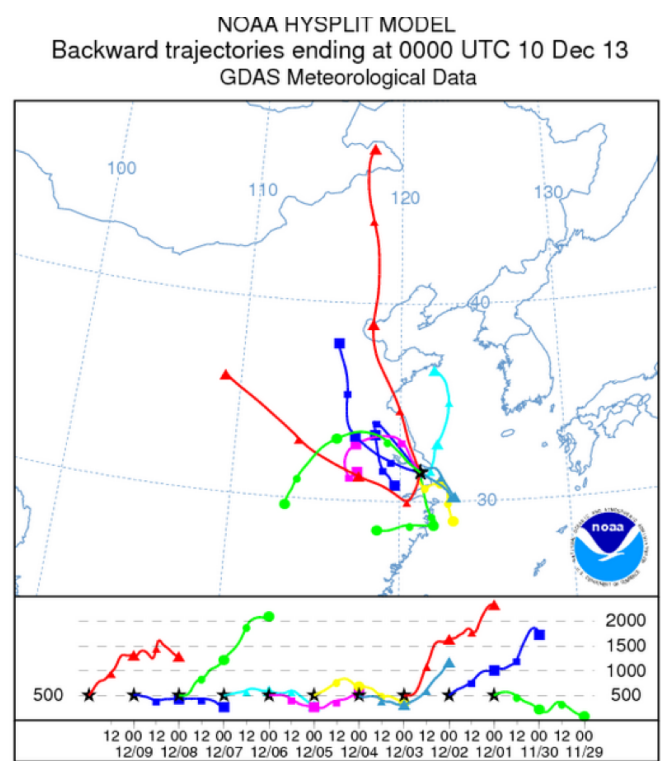

Figure 10. Air mass $48 \mathrm{~h}$ backward trajectories arriving at Shanghai from 1 to 10 December 2013. A new trajectory is started at 00:00 (UTC) and calculated every $24 \mathrm{~h}$.

\subsubsection{Impacts of air mass pathways}

HYSPLIT-4 model, developed by the Air Resources Laboratory (ARL) of the National Oceanic and Atmospheric Administration (NOAA) of the USA (Draxler and Rolph, 2003), was employed to compute $48 \mathrm{~h}$ air mass backward trajectories at $500 \mathrm{~m}$ height, starting at 00:00 and 12:00 UTC for each day. By doing so, we can identify and compile a full view of the possible source regions of pollutants.

According to those calculated trajectories plotted in Fig. 10, three types of air mass pathways were determined in summary. Firstly, the air mass wandered inside the region with shallow atmospheric boundary layer, accounting for $60 \%$ of total trajectories, which was in good agreement with stable synoptic conditions during the hazy episodes. This situation facilitates the accumulation of atmospheric pollutants and ultimately results in haze formation. Secondly, the subsidence flow from high altitude with minor horizontal movement, accounting for $30 \%$ of trajectories, dominated and brought in temporal clear sky between the hazy episodes on 2, 3 and 8 December. Thirdly, the air mass, originating from northern inland China at high altitude, traveled fast in a southerly direction across the Northern China Plain (NCP) and the eastern region of China (ERC), and finally arrived in Shanghai over a long distance on 10 December, accounting for $10 \%$ of trajectories. They are helpful to dilute the atmospheric pollutants and then end this haze event. Most possibly, a combination of local emissions and long-distance transportation of remote emissions exerts the joint effects to the pollutants during the haze event. 


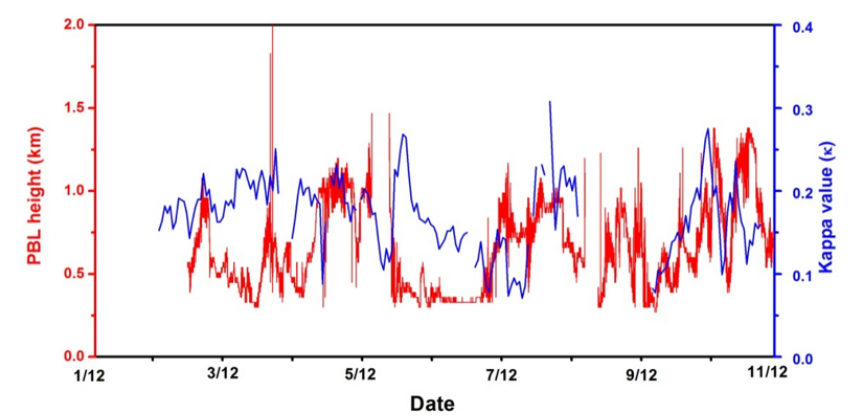

Figure 11. Time series of $1 \mathrm{~h}$ mean kappa value (i.e., $\kappa$ ) and $5 \mathrm{~min}$ mean PBL height from 1 to 10 December.

\subsubsection{Reduction of PBL height}

PBL plays a vital role in determining the vertical dispersion of air pollutants that are emitted naturally or artificially from the Earth's surface (Kim et al., 2007; Liu et al., 2013). Decreasing the height of PBL can normally hold the pollutants within the shallow surface layer, suppress the vertical atmospheric dilution and ultimately cause regional environment shrouded by pollution (Kim et al., 2007). In Shanghai, several field measurements have monitored that PBL height is usually low during hazy episodes (Leng et al., 2014b; Zhang et al., 2015). By utilizing the normalized lidar backscatter signal at $532 \mathrm{~nm}$, the PBL retrieval at 30 s resolution was derived in this study, and the time-height series were plotted in red line in Fig. 11. Overall, PBL height was negatively correlated with atmospheric visibility with $R^{2}$ of 0.63 , and averaged at $1.3 \mathrm{~km}$ during the clean periods and $0.6 \mathrm{~km}$ during the hazy episodes. From midday on 5 to the night on 6 December, the height of PBL decreased to $400 \mathrm{~m}$ lasting more than $30 \mathrm{~h}$, and $\mathrm{PM}_{2.5}$ during this period enhanced to over $600 \mu \mathrm{g} \mathrm{m}^{-3}, 5.4$ times the average of the clean periods. The lower PBL heights will retain more pollutants in the surface layer and cause the city to be surrounded by haze.

In theory, PBL basically evolves as a function of atmospheric thermal and dynamic factors, e.g., air temperature and wind speed (Liu et al., 2013). In fact, there is a feedback between atmospheric aerosol loading and PBL height. Briefly, the more ambient aerosols accumulate, the less solar radiation reaches to surface, which inevitably poses a disadvantageous effect on surface air temperature as well as a positive impact on ambient $\mathrm{RH}$, and further restricts the development of PBL. The low PBL height in turn forces the accumulation of aerosol particles in the high RH and shallow atmosphere, and ultimately degrades atmospheric visibility (Liu et al., 2013). Otherwise, more solar radiation arrives at the ground in case of clean sky, under those conditions the air temperature and PBL height increase while the ambient $\mathrm{RH}$ drops, which is unfavorable to the haze formation. This scientific issue involves many complicated atmospheric processes remaining poorly understood as well as deserving fur- ther study. As mentioned in Sects. 3.2.1 and 3.2.2, the YRD region was undergoing a large scale of weak high pressure with surface air moving slowly during the campaign. The air temperature retained at a low level which was not conductive to the development of PBL; thereby heavy air pollution took place and eventually resulted in visibility degradation. In short, the low PBL height is helpful for the increase of aerosol particles, hence favoring the occurrence of haze event.

\subsubsection{Aerosol composition and hygroscopicity}

As important components of ambient particles, particlephase water-soluble inorganic ions generally account for $30 \%$ of particulate matter in urban atmosphere, and are considered as a great contributor to the atmospheric visibility impairment because they hugely determine the ability of aerosol particles to uptake water vapor (Hillamo et al., 1998; Andrews et al., 2000; Chow et al., 2006; Seinfeld and Pandis, 2006). Also, they are essential participants in the formation, growth and evolution of nanoparticles by providing significant potential of surface chemical reactions (Wang et al., 2006b). In Shanghai, sulfate and nitrate have been evidently identified as great contributors to the occurrence of heavy particulate pollution events (Wang et al., 2006b; Sun et al., 2006; Fu et al., 2008), and $\mathrm{NH}_{3}$ plays a vital role in the enhancement of particulate sulfate and nitrate (Ye et al., 2011).

When ambient RH is high, those aerosols that are more hydrophilic can grow in diameter via uptake of water vapor, and through this way they can increase their ability of scattering light and cause atmospheric visibility impairment (Tang, 1996). A kappa value $\kappa$, describing particle hygroscopicity, was firstly introduced by Petters and Kreidenweis (2007) and employed here to investigate its relationship with haze formation. Assuming ambient aerosols are well internally mixed, the effective integrated $\kappa$ can be obtained through weighting their chemical compound volume factions,

$\kappa=\sum_{i}^{\varepsilon_{i} \kappa_{i}}$

where $\varepsilon_{i}$ is the volume fraction of chemical compounds in particles, and $\kappa_{i}$ is the effective $\kappa$ of individual chemical composition. Equation (5) has been widely used and described elsewhere in detail (Petters and Kreidenweis, 2008; Yue et al., 2011; Leng et al., 2014a, b). In this study, aerosol particle compositions were classified into three categories, and $\kappa_{i}$ and $\varepsilon_{i}$ for individual composition are listed in Table 1, of which "others" refers to $\mathrm{PM}_{10}-\left(\mathrm{SO}_{4}^{2-}+\mathrm{NO}_{3}^{-}+\mathrm{NH}_{4}^{+}+\mathrm{Cl}^{-}+\mathrm{Na}^{+}\right)$, and is viewed as a chemical compound with $\kappa_{i}=0$ (Yue et al., 2011). As a caveat, the contribution of water-soluble organic species is neglected in this analysis, which can result in an underestimate of the particle hygroscopicity. Figure 11 provides the time series of hourly averaged kappa values, with 


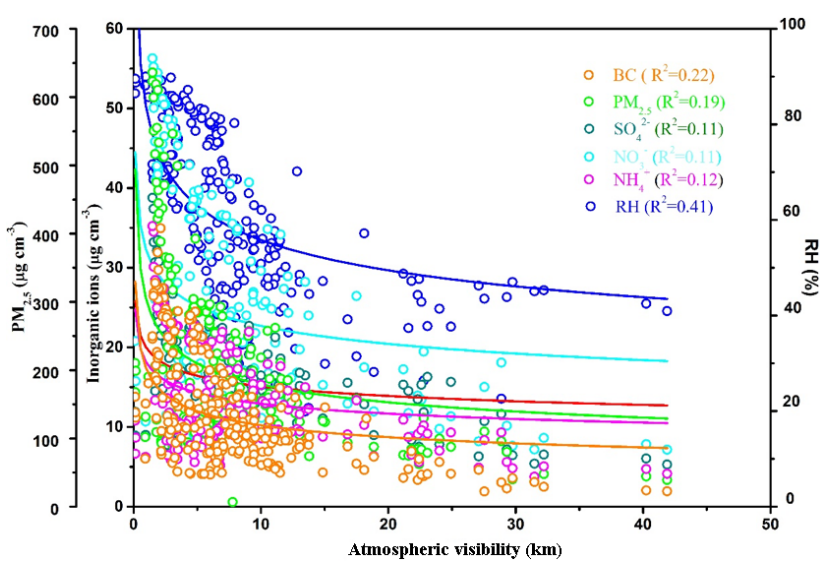

Figure 12. Scatter plots of $\mathrm{RH}, \mathrm{BC}, \mathrm{PM}_{2.5}$ and inorganic ions in particles vs. atmospheric visibility.

Table 1. Effective hygroscopicity parameters $(\kappa)$ and densities of the three category compositions.

\begin{tabular}{llrr}
\hline Species & Data source & $\kappa$ & $\begin{array}{r}\text { Density } \\
\left(\mathrm{g} \mathrm{cm}^{-3}\right)\end{array}$ \\
\hline Sulfate \& nitrate & $\mathrm{SO}_{4}^{2-}+\mathrm{NO}_{3}^{-}+\mathrm{NH}_{4}^{+}$ & 0.6 & 1.7 \\
Sodium chloride & $\mathrm{Cl}^{-}+\mathrm{Na}^{+}$ & 1 & 2.2 \\
Insoluble compounds & Others & 0 & 2.0 \\
\hline
\end{tabular}

higher $\kappa$ during the hazy episodes (0.22) and lower $\kappa$ during the clean periods $(0.15)$, indicating that aerosols are basically more hygroscopically responsible for haze occurrence during the pollution period.

With the aim of better understanding the potential contribution of individual water-soluble ions, $\mathrm{BC}$ and ambient RH to atmospheric visibility impairment, we run nonlinear regression analysis and the results are plotted in Fig. 12. The correlation between atmospheric visibility and individual ions, $\mathrm{BC}$ and $\mathrm{PM}_{2.5}$ was not so impressive with $R^{2}$ from 0.11 to 0.22 . However, it became more significant in view of ambient RH with $R^{2}$ of 0.41 . The result suggests that the atmospheric visibility impairment is less driven by watersoluble ions but largely induced by hygroscopicity, consistent with Tang (1996) and Jansen et al. (2014).

\subsubsection{Aerosol size spectra}

Atmospheric aerosol particles are usually divided into four classes according to their size distribution, i.e., nucleation mode $(<25 \mathrm{~nm})$, Aitken mode $(25-100 \mathrm{~nm})$, accumulation mode (100-1000 nm), and coarse mode (>1000 nm) (Zhang et al., 2010). The ability to determine the amount of visible light scattered by atmospheric aerosols relies strongly on their number size distributions, of which accumulation mode plays the major role yet coarse and nucleation mode exert a minor contribution (Cheng et al., 2008b). Numerous studies have observed the inter-relationship between atmospheric

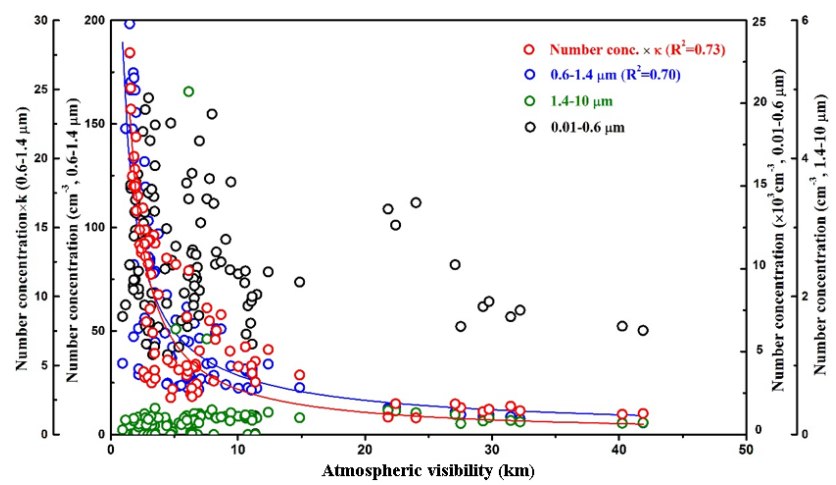

Figure 13. Scatter plots of aerosol number concentrations in ranges of $0.01-0.6,0.6-1.4$ and $1.4-10 \mu \mathrm{m}$, and aerosol number concentration multiplied by particle hygroscopicity (kappa value, $\kappa$ ) vs. atmospheric visibility.

visibility and aerosol number size distribution (Cheng et al., 2008a; Jansen et al., 2014). To be more specific, Kang et al. (2013) reported that the expected reciprocal relationship was found only between atmospheric visibility and aerosols in 600-1400 nm instead of other sizes.

Accordingly, aerosol particles were classified into three categories, i.e., $10-600 \mathrm{~nm}, 600 \mathrm{~nm}-1.4 \mu \mathrm{m}$ and $1.4-10 \mu \mathrm{m}$. By doing so, their nonlinear regression analysis with atmospheric visibility was computed and the results were given in Fig. 13. As expected, no significant correlation was derived between atmospheric visibility and aerosol size of 10 $600 \mathrm{~nm}$ and $1.4-10 \mu \mathrm{m}$, whereas aerosols in $600 \mathrm{~nm}-1.4 \mu \mathrm{m}$ indeed controlled atmospheric visibility to a great extent with $R^{2}$ of 0.70 , which further improved to 0.73 if we combined aerosol hygroscopic potential well determined by its sizeresolved composition. In this study, aerosol number concentrations in $600 \mathrm{~nm}-1.4 \mu \mathrm{m}$ were on average $110 \mathrm{~cm}^{-3}$ during the hazy episodes and $43 \mathrm{~cm}^{-3}$ during the clean periods. The atmospheric visibility was dependent on aerosol number size distribution and its impairment during the hazy episodes was mostly caused by the enhancement of aerosol concentration in $600 \mathrm{~nm}-1.4 \mu \mathrm{m}$.

\section{Summary and conclusion}

A historic haze event was fully analyzed for the temporal variations of aerosol optical, physical and chemical properties and meteorological conditions, as well as the formation and evolution mechanism. During the event, atmospheric visibility decreased dramatically, while particle burden, water-soluble inorganic ions, aerosol scattering and absorption coefficients evidently increased. In particular, particulate mass burden produced a new historic record by exceeding $600 \mu \mathrm{g} \mathrm{m}^{-3}$.

Many factors in combination drove the formation and evolution of this severe haze event. For most of the measured 
period, the YRD was under the control of a slowly migrating anti-cyclone to result in subsidence airflow and relatively stagnant conditions. The subsidence airflow suppressed vertical mixing and favored the accumulation of air pollutants within the shallow atmospheric layer. Moreover, the calm surface wind subsidence airflow was not constructive to the horizontal dispersion of air pollutants which further promoted the haze formation. In summary, the significant increase of regional pollutants from anthropogenic emissions was the basic cause of this haze formation, and the unfavorable meteorological conditions played as the external reason.

Acknowledgements. This research is supported by the National Key Technology R\&D Program of Ministry of Science and Technology (2014BAC16B01), the National Natural Science Foundation of China (41475109,21577021, 21377028 ), and partly by the Jiangsu Collaborative Innovation Center for Climate Change, and the Key Laboratory for Aerosol-Cloud-Precipitation of China Meteorological Administration (KDW1401) and the Laboratory of Meteorological Disaster of Ministry of Education (KLME1416).

Edited by: S. S. Gunthe

Reviewed by: three anonymous referees

\section{References}

Andreae, M. O., Jones, C. D., and Cox, P. M.: Strong present-day aerosol cooling implies a hot future, Nature, 435, 1187-1190, 2005.

Andrews, E., Saxena, P., Mussara, S., Hildemann, L. M., Koutrakis, P., McMurry, P. H., Olmez, I., and White, W. H.: Concentration and composition of atmospheric aerosols from the 1995 SEAVS experiment and a review of the closure between chemical and gravimetric measurements, J. Air Waste Manage., 50, 648-664, 2000.

Bell, M. L., Cifuentes, L. A., Davis, D. L., Cushing, E., and Telles, A. G.: Gouveia, N. Environmental health indicators and a case study of air pollution in Latin American cities, Environ. Res., 111, 57-66, 2011.

Bergin, M., Cass, G. R., Xu, J., Fang, F., Zeng, L. M., Yu T., Salmon, L. G., Kiang, C. S., Tang, X. Y., Zhang, Y. H., and Chameides, W. L.: Aerosol radiative, physical, and chemical properties in Beijing during June 1999, J. Geophys. Res., 106, 17969-17980, 2001.

Boers, R. and Eloranta, E. W.: Lidar measurements of the atmospheric entrainment zone and the potential temperature jump across the top of the mixed layer, Bound.-Lay. Meteorol., 34, 357-375, 1986.

Bond, T. C. and Bergstrom, R. W.: Light Absorption by Carbonaceous Particles: An Investigative Review, Aerosol Sci. Technol., 40, 27-47, 2006.

Brooks, I. M.: Finding boundary layer top: application of a wavelet covariance transform to lidar backscatter profiles, J. Atmos. Ocean. Tech., 20, 1092-1105, 2003.

Campbell, J. R., Hlavka, D. L., Welton, E. J., Flynn, C. J., Turner, D. D., Spinhirne, J. D., Scott, V. S., and Hwang, I. H.: Full-time, eye-safe cloud and aerosol lidar observation at atmospheric radiation measurement program sites: Instruments and data processing, J. Atmos. Ocean Tech., 19, 431-442, 2002.

Cao, J., Xu, H., Xu, Q., Chen, B., and Kan, H.: Fine particulate matter constituents and cardiopulmonary mortality in a heavily polluted Chinese city, J. Environ. Health Persp., 120, 373-378, 2012.

Che, H. Z., Zhang, X. Y., Li, Y., Zhou, Z. J., Qu, J. J., and Hao, X. J.: Haze trends over the capital cities of 31 provinces in China, 1981-2005, Theor. Appl. Climatol., 97, 235-242, 2009.

Chen, L. W. A., Chow, J. C., Doddridge, B. G., Dickerson, R. R., Ryan, W. F., and Mueller, P. K.: Analysis of a summertime $\mathrm{PM}_{2.5}$ and haze episode in the mid-Atlantic region, J. Air Waste Mange., 53, 946-956, 2003.

Cheng, T. T., Han, Z. W., Zhang, R. J., Du, H. H., Jia, X., Wang, J. J., and Yao, J. Y.: Black carbon in a continental semi-arid area of Northeast China and its possible sources of fire emission, J. Geophys. Res., 115, D23204, doi:10.1029/2009JD013523, 2010.

Cheng, Y. F., Wiedensohler, A., Eichler, H., Heintzenberg, J., Tesche, M., Ansmann, A., Wendisch, M., Su, H., Althausen, D., Herrmann, H., Gnauk, T., Bruggemann, E., Hu, M., and Zhang, Y. H.: Relative humidity dependence of aerosol optical properties and direct radiative forcing in the surface boundary layer at Xinken in Pearl River Delta of China: An observation based numerical study, Atmos. Environ., 42, 6373-6397, 2008a.

Cheng, Y. F., Wiedensohler, A., Eichler, H., Su, H., Gnauk, T., Brüggemann, E., Herrmann, H., Heintzenberg, J., Slanina, J., Tuch, T., Hu, M., and Zhang, Y. H.: Aerosol optical properties and related chemical apportionment at Xinken in Pearl River Delta of China, Atmos. Environ., 42, 6351-6372, 2008b.

Chow, J. C., Chen, L. W. A., Watson, J. G., Lowenthal, D. H., Magliano, K. A., Turkiewicz, K., and Lehrman, D. E.: $\mathrm{PM}_{2.5}$ cheimcal composition and spatiotemporal variability during the California regional $\mathrm{PM}_{10} / \mathrm{PM}_{2.5}$ air quality study (CRPAQS), J. Geophys. Res., 111, D10S04, doi:10.1029/2005JD006457, 2006.

Cohn, S. A. and Angevine, W. M.: Boundary layer height and entrainment zone thickness measured by lidars and wind-profiling radars, J. Appl. Meteorol., 39, 1233-1247, 2000.

Draxler, R. R. and Rolph, G. D.: HYSPLIT (Hybrid Single-Particle Lagrangian Integrated Trajectory) Model access via NOAA ARL READY Website, avaialble at: http://www.arl.noaa.gov/ready/ hysplit4.htm (last access: 1 April 2015), NOAA Air Resources Laboratory, Silver Spring, MD, 2003.

Du, H. H., Kong, L. D., Cheng, T. T., Chen, J. M., Du, J. F., Li, L., Xia, X. G., Leng, C. P., and Huang, G. H.: Insights into summertime haze pollution events over Shanghai based on online water-soluble ionic composition of aerosols, Atmos. Environ., 45, 5131-5137, 2011.

Fu, Q. Y., Zhuang, G. S., Wang, J., Xu, C., Huang, K., Li, J., Hou, B., Lu, T., and Streets, D. G.: Mechanism of formation of the heaviest pollution episode ever recorded in the Yangtze River Delta, China, Atmos. Environ., 42, 2023-2036, 2008.

Gao, J., Wang, J., Cheng, S., Xue, L.-K., Yan, H.-Z., Hou, L.-J., Jiang, Y.-Q., and Wang, W.-X.: Number concentration and size distributions of submicron particles in Jinan urban area: Characteristics in summer and winter, J. Environ. Sci., 19, 1466-1473, 2007.

Gao, J., Wang, T., Zhou, X. H., Wu, W. S., and Wang, W. X.: Measurement of aerosol number size distributions in the Yangtze 
River delta in China: formation and growth of particles under polluted conditions, Atmos. Environ., 43, 829-836, 2009.

Hansen, A. D. A., Rosen, H., and Novakov, T.: The aethalometer-an instrument for the real-time measurement of optical absorption by aerosol particles, Sci. Total Environ., 36, 191-196, 1984.

He, K. B., Yang, F. M., Ma, Y. L., Zhang, Q., Yao, X. H., Chan, C. K., Cadle, S., Tai Chan, T., and Mulaw, P.: The characteristics of $\mathrm{PM}_{2.5}$ in Beijing, China, Atmos. Environ., 35, 4959-4970, 2001.

Hillamo, R., Allegrini, I., Sparapani, R., and Kerminen, V. M.: Mass size distributions and precursor gas concentrations of major inorganic ions in Antarctica aerosol, Int. J. Environ. Anal. Chem., 71, 357-369, 1998.

Huebert, B. J., Wang, M. X., and Lv, W. X.: Atmospheric nitrate, sulfate, ammonium and calcium concentrations in China, Tellus B, 4, 260-269, doi:10.1111/j.1600-0889.1988.tb00296.x, 1988.

Huebert, B. J., Bates, T., Russell, P. B., Shi, G. Y., Kim, Y. J., Kawamura, K., Carmichael, G., and Nakajima, T.: An overview of ACE-Asia: Strategies for quantifying the relationships between Asian aerosols and their climatic impacts, J. Geophys. Res., 108, $1-20,2003$

IPCC: Climate Change 2013: The Physical Science Basis. Contribution of Working Group I to the Fifth Assessment Report of the Intergovernmental Panel on Climate Change, edited by: Joussaume, S. Penner, J., and Tangang, F., IPCC, Stockholm, 2013.

Jansen, R. C., Chen, J., and Hu, Y.: The impact of nonlocal ammonia on submicron particulate matter and visibility degradation in urban shanghai, Adv. Meteorol., 2014, 534675, doi:10.1155/2014/534675, 2014

Kang, H. Q., Zhu, B., Su, J. F., Wang, H. L., Zhang, Q. C., and Wang, F.: Analysis of a long-lasting haze episode in Nanjing, China, Atmos. Res., 120-121, 78-87, 2013.

Kim, S. W., Yoon, S. C., Won, J. G., and Choi, S. C.: Ground-based remote sensing measurements of aerosol and ozone in an urban area: A case study of mixing height evolution and its effect on ground-level ozone concentrations, Atmos. Environ., 41, 70697081, 2007.

Lance, S., Medina, J., Smith, J. N., and Nenes, A.: Mapping the operation of the DMT Continuous Flow CCN counter, Aerosol Sci. Tech., 40, 242-254, 2006.

Leng, C., Zhang, Q., Zhang, D., Xu, C., Cheng, T., Zhang, R., Tao, J., Chen, J., Zha, S., Zhang, Y., Li, X., Kong, L., and Gao, W.: Variations of cloud condensation nuclei $(\mathrm{CCN})$ and aerosol activity during fog-haze episode: a case study from Shanghai, Atmos. Chem. Phys., 14, 12499-12512, doi:10.5194/acp-1412499-2014, 2014a.

Leng, C., Zhang, Q., Tao, J., Zhang, H., Zhang, D., Xu, C., Li, X., Kong, L., Cheng, T., Zhang, R., Yang, X., Chen, J., Qiao, L., Lou, S., Wang, H., and Chen, C.: Impacts of new particle formation on aerosol cloud condensation nuclei $(\mathrm{CCN})$ activity in Shanghai: case study, Atmos. Chem. Phys., 14, 11353-11365, doi:10.5194/acp-14-11353-2014, 2014b.

Leng, C. P., Cheng, T. T., Chen, J. M., Zhang, R. J., Tao, J., Huang, G. H., Zha, S. P., Zhang, M. G., Fang, W., Li, X., and Li, L.: Measurements of surface cloud condensation nuclei and aerosol activity in downtown Shanghai, Atmos. Environ., 69, 354-361, 2013.

Lee, D. O.: Trends in summer visibility in London and Southern England 1962-1979, Atmos. Environ., 17, 151-159, 1983.
Li, C., Lau, K. H., Mao, J., and Chu, D. A.: Retrieval, validation and application of the 1-km aerosol optical depth from MODIS measurements over Hong Kong, IEEE T. Geosci. Remote, 43, 2650-2658, 2005.

Liu, X. G., Li, J., Qu, Y., Han, T., Hou, L., Gu, J., Chen, C., Yang, Y., Liu, X., Yang, T., Zhang, Y., Tian, H., and Hu, M.: Formation and evolution mechanism of regional haze: a case study in the megacity Beijing, China, Atmos. Chem. Phys., 13, 4501-4514, doi:10.5194/acp-13-4501-2013, 2013.

Lohmann, U. and Feichter, J.: Global indirect aerosol effects: a review, Atmos. Chem. Phys., 5, 715-737, doi:10.5194/acp-5-7152005, 2005.

Malm, W. C. and Day, D. E.: Estimates of aerosol species scattering characteristics as a function of relative humidity, Atmos. Environ., 35, 2845-2860, 2001.

McNulty, R. P.: The effect of air pollutants on visibility in fog and haze at New York city, Atmos. Environ., 2, 625-628, 1968.

Menut, L., Flamant, C., Pelon, J., and Flamant, P. H.: Urban boundary-layer height determination from lidar measurements over the Paris area, Appl. Optics, 38, 945-954, 1999.

Ohta, S. and Okita, T.: A chemical characterization of atmospheric aerosol in Sapporo, Atmos. Environ., 24A, 815-822, 1990.

Petters, M. D. and Kreidenweis, S. M.: A single parameter representation of hygroscopic growth and cloud condensation nucleus activity, Atmos. Chem. Phys., 7, 1961-1971, doi:10.5194/acp-71961-2007, 2007.

Petters, M. D. and Kreidenweis, S. M.: A single parameter representation of hygroscopic growth and cloud condensation nucleus activity - Part 2: Including solubility, Atmos. Chem. Phys., 8, 6273-6279, doi:10.5194/acp-8-6273-2008, 2008.

Petzold, A., Kopp, C., and Niessner, R.: The dependence of the specific attenuation cross-section on black carbon mass fraction and particle size, Atmos. Environ., 31, 661-672, 1997.

Poppe, D., Wallasch, M., and Zimmermann, J.: The dependence of the concentration of $\mathrm{OH}$ on its precursors under moderately polluted conditions: a model study, J. Atmos, Chem., 16, 61-78, 1993.

Ramanathan, V., Crutzen, P. J., Kiehl, J. T., and Rosenfeld, D.: Aerosols, climate, and the hydrological cycle, Science, 294, 2119-2124, 2001.

Ritesh, G., Christina, H., Menas, K., and Si-Chee, T.: Influences of winter haze on fog/low cloud over the Indo-Gangetic plains, J. Geophys. Res., 112, D05207, doi:10.1029/2005JD007036, 2007.

Roberts, G. C. and Nenes, A.: A continuous-flow streamwise thermal-gradient $\mathrm{CCN}$ chamber for atmospheric measurements, Aerosol Sci. Tech., 39, 206-221, 2006.

Schichtel, B. A., Husar, R. B., Falke, S. R., and Wilson, W. E.: Haze trends over the United States, 1980-1995, Atmos. Environ., 35, 5205-5210, 2001.

Sun, Y. L., Zhuang, G. S., Wang, Y., Han, L. H., Guo, J. H., Dan, M., Zhang, W. J., Wang, Z. F., and Hao, Z. P.: The air-borne particulate pollution in Beijing-Concentration, composition, distribution and sources, Atmos. Environ., 38, 5991-6004, 2004.

Sun, Y. L., Zhuang, G. S., Tang, A. H., Wang, Y., and An, Z. S.: Chemical characteristics of $\mathrm{PM}_{2.5}$ and $\mathrm{PM}_{10}$ in haze-fog Episodes in Beijing, Environ. Sci. Technol., 40, 3148-3155, 2006. 
Quinn, P. K. and Bates, T.: North American, Asian, and Indian haze: Similar regional impacts on climate?, Geophys. Res. Lett., 30, 1555, doi:10.1029/2003GL016934, 2003.

SEB: Shanghai Environmental Bulletin 2010, Shanghai Environmental Protection Bureau, Shanghai, available at: http://www. envir.gov.cn/law/bulletin/2010/ (last access: 13 July 2016), 2010.

Seinfeld, J. H. and Pandis, S. N.: Atmospheric Chemistry and Physics: From Air Pollution to Climate Change, 2nd Edn., John Wiley \& Sons, New York, USA, 57-58 and 381-383, 2006.

Tan, H. H., Duan, J. C., He, K. B., Ma, Y. L., Duan, F. K., Chen, Y., and $\mathrm{Fu}, \mathrm{J}$. M.: Chemical characteristics of $\mathrm{PM}_{2.5}$ during a typical haze episode in Guangzhou, J. Environ. Sci., 21, 774-781, 2009.

Tang, I. N.: Chemical and size effects of hygroscopic aerosols on light scattering coefficients, J. Geophys. Res., 101, 1924519250, 1996.

Tie, X. and Cao, J.: Aerosol pollution in China: Present and future impact on environment, Particuology, 7, 426-431, 2009.

Tuch, T., Brand, P., Wichmann, H. E., and Heyder, J.: Variation of particle number and mass concentration in various size ranges of ambient aerosols in Eastern Germany, Atmos. Environ., 31, 4193-4197, 1997.

Wang, Y., Zhuang, G. S., Zhang, X. Y., Huang, K., Xu, C., Tang, A. H., Chen, J. M., and An, Z. S.: The ion chemistry, seasonal cycle, and sources of $\mathrm{PM}_{2.5}$ and TSP aerosol in Shanghai, Atmos. Environ., 40, 2935-2952, 2006a.

Wang, Y., Zhuang, G. S., Sun, Y. L., and An, Z. S.: The variation of characteristics and formation mechanisms of aerosols in dust, haze, and clear days in Beijing, Atmos. Environ., 40, 6579-6591, 2006b.

Weingartner, E., Saathoff, H., Schnaiter, M., Streit, N., Bitnar, B., and Baltensperger, U.: Absorption of light by soot particles: determination of the absorption coefficient by means of aethalometers, J. Aerosol Sci., 34, 1445-1463, 2003.

Welton, E. J. and Campbell, J. R.: Micropulse lidar signals: Uncertainty analysis, J. Atmos. Ocean. Tech., 19, 2089-2094, 2002.

Welton, E. J., Voss, K. J., Quinn, P. K., Flatau, P. J., Markowicz, K., Campbell, J. R., Spinhirne, J. D., Gordon, H. R., and Johnson, J. E.: Measurements of aerosol vertical profiles and optical properties during INDOEX 1999 using micropulse lidars, J. Geophys. Res.-Atmos., 107, 8019, doi:10.1029/2000JD000038, 2002.

Woo, K. S., Chen, D. R., Pui, D. Y. H., and McMurry, P. H.: Measurements of Atlanta aerosol size distributions: observations of ultrafine particle events, Aerosol Sci. Tech., 34, 75-87, 2001.

Wu, D., Tie, X., Li, C., Ying, Z., Lau, A. K.-H., Huang, J., Deng, X., and $\mathrm{Bi}, \mathrm{X}$.: An extremely low visibility event over the Guangzhou region: a case study, Atmos. Environ., 39, 6568-6577, 2005.

Wu, D., Bi, X., Deng, X., Li, F., Tan, H., Liao, G., and Huang, J.: Effects of atmospheric haze on the deterioration of visibility over the Pearl River Delta, Acta Meteorol. Sin., 64, 510-517, 2006.

Xiao, F., Brajer, V., and Mead, R. W.: Blowing in the wind: the impact of China's Pearl River Delta on Hong Kong's air quality, Sci. Total Environ., 367, 96-111, 2006.
Xu, W. Y., Zhao, C. S., Ran, L., Deng, Z. Z., Liu, P. F., Ma, N., Lin, W. L., Xu, X. B., Yan, P., He, X., Yu, J., Liang, W. D., and Chen, L. L.: Characteristics of pollutants and their correlation to meteorological conditions at a suburban site in the North China Plain, Atmos. Chem. Phys., 11, 4353-4369, doi:10.5194/acp-114353-2011, 2011.

Yan, P., Tang, J., Huang, J., Mao, J. T., Zhou, X. J., Liu, Q., Wang, Z. F., and Zhou, H. G.: The measurement of aerosol optical properties at a rural site in Northern China, Atmos. Chem. Phys., 8, 2229-2242, doi:10.5194/acp-8-2229-2008, 2008.

Yan, P., Pan, X., Tang, J., Zhou, X., Zhang, R., and Zeng, L.: Hygroscopic growth of aerosol scattering coefficient: A comparative analysis between urban and suburban sites at winter in Beijing, Particuology, 7, 52-60, 2009.

Yao, X. H., Chan, C. K., Fang, M., Cadle, S., Chan, T., Mulawa, P., He, K. B., Ye, B. M.: The water-soluble ionic composition of $\mathrm{PM}_{2.5}$ in Shanghai and Beijing, China, Atmos. Environ., 36, 4223-4234, 2002.

Ye, X. N., Ma, Z., Zhang, J. C., Du, H. H., Chen, J. M., Chen, H., Yang, X., Gao, W., and Geng, F. H.: Important role of ammonia on haze formation in Shanghai, Environ. Res. Lett., 6, 024019, doi:10.1088/1748-9326/6/2/024019, 2011.

Yue, D. L., Hu, M., Zhang, R. J., Wu, Z. J., Su, H., Wang, Z. B., Peng, J. F., He, L. Y., Huang, X. F., Gong, Y. G., and Wiedensohler, A.: Potential contribution of new particle formation to cloud condensation nuclei in Beijing, Atmos. Environ., 45, 6070-6077, 2011.

Zhang, M., Wang, X. M., Chen, J. M., Cheng, T. T., Wang, T., Yang, X., Gong, Y. G., Geng, F. H., and Chen, C. H.: Physical characterization of aerosol particles during the Chinese New Year's firework events, Atmos. Environ., 44, 5191-5198, 2010.

Zhang, Q. C., Zhu, B., Su, J. F., and Wang, H. L.: Characteristes of aerosol water-soluble inorganic ions in three types air-pollution incidents of Nanjing City, Environ. Sci., 33, 1944-1951, 2012 (in Chinese).

Zhang, Y. W., Zhang, Q., Leng, C. P., Zhang, D., Cheng, T., Tao, J., Zhang, R., and He, Q.: Evolution of Aerosol Vertical Distribution During Particulate Pollution Events in Shanghai, J. Meteorol. Res., 29, 385-399, 2015.

Zhao, P. S., Dong, F., He, D., Zhao, X. J., Zhang, X. L., Zhang, W. Z., Yao, Q., and Liu, H. Y.: Characteristics of concentrations and chemical compositions for $\mathrm{PM}_{2.5}$ in the region of Beijing, Tianjin, and Hebei, China, Atmos. Chem. Phys., 13, 4631-4644, doi:10.5194/acp-13-4631-2013, 2013.

Zhao, X. J., Zhao, P. S., Xu, J., Meng,, W., Pu, W. W., Dong, F., He, D., and Shi, Q. F.: Analysis of a winter regional haze event and its formation mechanism in the North China Plain, Atmos. Chem. Phys., 13, 5685-5696, doi:10.5194/acp-13-5685-2013, 2013. 